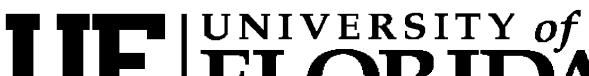 FLORIDA \\ IFAS Extension
}

\section{Forest Management in the Interface: Reducing Fire Risk ${ }^{\mathbf{1}}$}

\author{
Bruce Hull, Sarah F. Ashton, Rien M. Visser, and Martha C. Monroe ${ }^{2}$
}

Fire is one of the most serious and publicized challenges facing interface forest management. Wildfires dramatically change forest vegetation, affect human health, and cause millions of dollars worth of damage to homes, businesses, timber, and tourism.

Fire is a common ecological process in the South. There typically are more fire ignitions and acres burned in the South than any other region in the United States (Gramley 2005). Managing interface fire is especially challenging. Some landowners and interface residents object to fire as a management tool because they think it degrades forest aesthetics and forest health. Landowners and interface residents who understand the role of fire in forest health and who are willing to actively manage their forests with fire, still struggle to use fire because of the presence of structures; the fragmented quality of interface forests; the limited number of days with appropriate weather; the negative impacts of smoke on human health and driving safety; liability issues; and the difficulty predicting when weather, fuels, and winds will be appropriate for burning (Monroe 2002; Brose and Wade 2002).
Despite these challenges, wildfire and prescribed fire remain important in many southern forest ecosystems. These ecosystems depend on fire to release nutrients, improve wildlife habitat, control competing vegetation, and germinate seeds. If communities want to sustain these fire-dependent ecosystems, then fire must remain a part of the southern landscape. This means people need to be more comfortable with fire as a management tool.

\section{Firewise Communities}

Communities in fire-prone ecosystems need a landscape-level Firewise plan to minimize the risk of wildfire damage. In fire-dependent ecosystems the question is not whether a fire will come, but when it will come. Communities that plan accordingly can protect life and property values while sustaining a fire-dependent ecosystem. Community preparation can include land use planning and policy as well as training and equipment for landscape management. Large communities with fire departments should work with local forest and fire agencies to enhance their skills and equipment.

1. This document FOR 179, is one of the Forest Management in the Interface series of the School of Forest Resources and Conservation, Florida Cooperative Extension Services, Institute of Food and Agricultural Sciences, University of Florida. This fact sheet was first published in 2006 as part of Changing Roles: Wildland-Urban Interface Professional Development Program. It was reviewed and revised for EDIS in July 2008 . Visit the EDIS Web Site at http://edis.ifas.ufl.edu.

2. Bruce Hull, professor, Sarah F. Ashton, program assistant, and Rien M. Visser, associate professor, Virginia Polytechnic Institute and State University, Department of Forestry, Blacksburg, VA 24061. Martha C. Monroe, associate professor, School of Forest Resources and Conservation, Institute of Food and Agricultural Sciences, University of Florida, Gainesville, Fla 32611-0410.

The Institute of Food and Agricultural Sciences (IFAS) is an Equal Opportunity Institution authorized to provide research, educational information and other services only to individuals and institutions that function with non-discrimination with respect to race, creed, color, religion, age, disability, sex, sexual orientation, marital status, national origin, political opinions or affiliations. U.S. Department of Agriculture, Cooperative Extension Service, University of Florida, IFAS, Florida A. \& M. University Cooperative Extension Program, and Boards of County Commissioners Cooperating. Larry Arrington, Dean 
Large open spaces such as parks, golf courses, and agricultural districts could separate communities from forested areas that could burn during periods of drought. Zoning codes and community land-use plans should ensure that these areas are not developed with houses or densely planted with trees (National Interagency Fire Center 2005; National Firewise Organization 2005; Southern Center for Urban-Wildland Interface Research and Information 2004).

\section{Firewise Structures}

There are numerous tips for firewise design of structures. In general, structures should be made of low or nonflammable materials and should be maintained to reduce the chances of embers or radiant heat igniting vulnerable areas (National Firewise Organization 2005):

- Roofs should be Class A fiberglass shingles, tile, or metal rather than wood.

- Siding should be brick, stone, concrete, stucco, or some other nonflammable substance rather than wood (vinyl is noncombustible, but melts from radiant heat).

- Houses should be built at ground level instead of on stilts where fire can ignite vegetation or debris underneath. Where houses must be elevated because of flooding problems, care should be taken to enclose crawl spaces to keep fire and fuel from blowing underneath.

- Gutters, crawlspaces, and other nooks and crannies where fuel can accumulate should be sealed and/or regularly cleaned.

-Wood decks should be avoided, enclosed with fire resistant materials, or protected by sprinkler systems.

- All windows should be of double-paned, insulated glass for better protection against radiant heat. Vegetation near large windows should be avoided because heat will shatter glass. Tempered glass can mitigate some but not all risk.

- Internal and external sprinkler systems can be installed.
- An emergency water supply should be available to assist in fire fighting.

- The driveway should be large enough to accommodate fire equipment (i.e., at least 12 wide by 15 high).

- There should be at least two exits from each neighborhood.

\section{Firewise Landscaping around Structures}

Firewise landscaping creates a defensible space around a structure making it less likely to burn when fire sweeps through a community. There are three primary steps to reduce wildfire risk: (1) remove sources of fuel near structures, (2) create a landscape resistant to fire, and (3) perform regular maintenance.

Flammable trees and shrubs should be replaced with turf or groundcover near structures. The width of this groundcover firebreak depends upon the slope of the terrain, but recommendations vary from 30 feet for relatively flat terrain to as much as 100 feet for steep terrain (because fires run uphill and can more easily reach structures). Shrubs and ladder fuels that can help fire jump into the canopy and onto roofs should be removed in this defensible zone. Trees should be widely spaced so canopies do not touch when mature and ladder fuels underneath them are removed. Standing or downed dead trees, shrubs, or other sources of fuel should be away from the structure.

The phrase "lean, clean, and green" captures the essence of firewise landscaping. Lean implies small amounts of flammable vegetation, widely spaced. Clean implies no accumulation of dead material that can act as fuels. Green implies healthy and moist landscaping during fire season (The National Interagency Fire Center 2005; National Firewise Organization 2005; Long and Randall, 2004). There are no fire-proof plants, but some plants are less flammable than others (Behm et al. 2004; Doran, Randall, and Long 2004).

The following characteristics can be used to select plants less likely to contribute to a home ignition: 
- High moisture content. The moisture content of leaves and branches retards ignition.

- Broad and thick leaves. Thin leaves or needles tend to dry out quickly and ignite easily.

- Low chemical content. The presence of oils or other chemicals in the leaves and branches can increase flammability.

\section{- Open and loose branching patterns.}

- Deciduousness. Deciduous plants are generally less flammable than evergreens.

- Low amounts of dead materials. The accumulation of dead leaves and branches held on plants can increase flammability.

For example, avoid the following plants near a structure:

- Saw palmetto (Serenoa repens) accumulates dead leaves (fronds); dense, flammable leaves are close to ground; and is evergreen.

- Juniper (Juniperus spp.) - small needlelike evergreen leaves contain resins, and the plant often holds dead branches.

- Mountain laurel (Kalmia latifolia) younger plants have dense, evergreen leaves and branches close to ground. Older plants may develop a tree form with open sparse branching that is less flammable.

Resource managers often face challenges implementing firewise landscaping because landowners resist modifying or removing vegetation from around their houses. Some residents worry that firewise landscaping conflicts with their goals to maximize aesthetics and privacy, both of which are enhanced by vegetation around the structure. Many landowners live in interface forests because they want to be near forest vegetation. Firewise practices remove some of this vegetation, changing the look and feel of the landscape. Landowners may also fear losing the cooling shade of trees or the wildlife habitat that dense vegetation provides. Some landowners may ignore firewise principles because they care more about living in nature and protecting nature than they care about losing their property to fire. Therefore they are willing to live with the risk of property loss in order to minimize disruption to natural systems (Figure 1 and Figure 2).

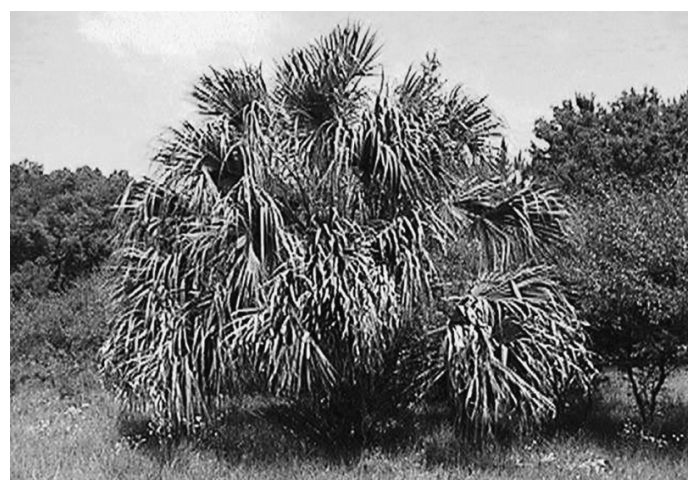

Figure 1. The dead or dying fronds on this cabbage palm increase its overall flammability and create a fire hazard when in close proximity to a house. Credits: Photo: J. Douglas Doran

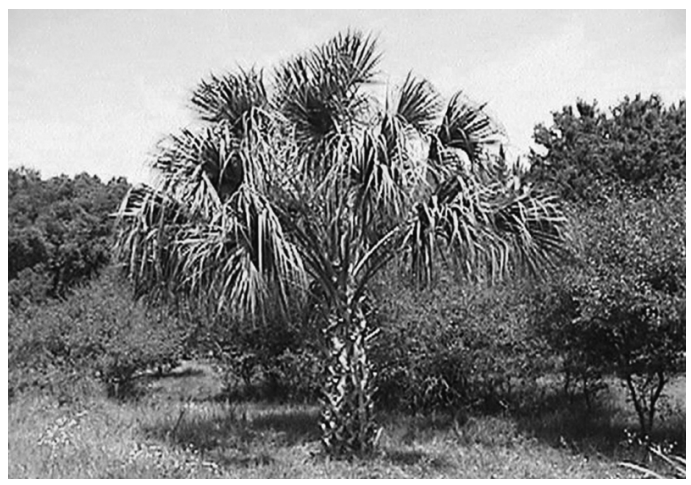

Figure 2. Reduce the fire hazard by removing the dead fronds. Credits: Photo: J. Douglas Doran

Many of these objections can be overcome, at least in part. Demonstration projects and educational programs help landowners find workable compromises between firewise landscaping principles and concerns about aesthetics, shade, privacy, and wildlife habitat (Monroe, Babb, and Heuberger 1999). Concerns about protecting nature can be countered with educational programs that emphasize the role of fire in the regeneration and life cycle of many species. Presentations of firewise techniques to landowners need to cautiously present these potential conflicts and show examples of how they have been resolved. Illustrations can provide landowners multiple views of landscape designs that are firewise, aesthetic, and private (Southern Center for 
Wildland-Urban Interface Research and Information 2004; Monroe and Nelson 2004).

\section{Fuel Reduction}

The best way to minimize risk of fire damage is to reduce fuel from around the structure and from firebreaks around the community. Methods of fuel reduction include mechanical, prescribed fire, herbicide, and animal grazing.

Mechanical thinning involves removing smaller trees, usually small diameter and low-value species. It can reduce fuel load and ladder fuels in the understory. In small stands, especially those closer to homes, manual thinning with loppers or small, safety-enhanced chainsaws is sufficient. In large or commercial stands, thinning is usually achieved through a combination of mechanical and manual processes with bush hogs or heavy duty choppers, chainsaws, loppers, and brush cutters. This equipment can be difficult and dangerous to operate, so caution should be exercised in recommending its use. Stand thinning can evoke ideological opposition from landowners concerned that active management degrades forest health or reduces regional esthetics. Stand thinning also is expensive if there is not an available market for the wood extracted during the thinning. Mowing the rough areas of golf courses or tilling agricultural fields may be required to maintain reduced fuel loads in zones that serve as firebreaks around communities.

Prescribed burning is the systematic and deliberate setting of low-intensity, easily-controlled fires to burn away dangerous fuels and reduce risk of catastrophic wildfire. About five to six million acres of non-industrial private land are burned with prescribed fire in the South each year (Haines, Busby, and Cleaves 2001; Williston, Balmer, and Tomczak 2001). Prescribed burning requires a great deal of skill and resources to minimize risk involved with fire that escapes control. Certification, burn plans, and permits may be required by state forestry agencies. (Figure 3)

Although respected by natural resource managers as a valuable and applicable tool in the South, prescribed fire faces some opposition from interface landowners and communities. In some

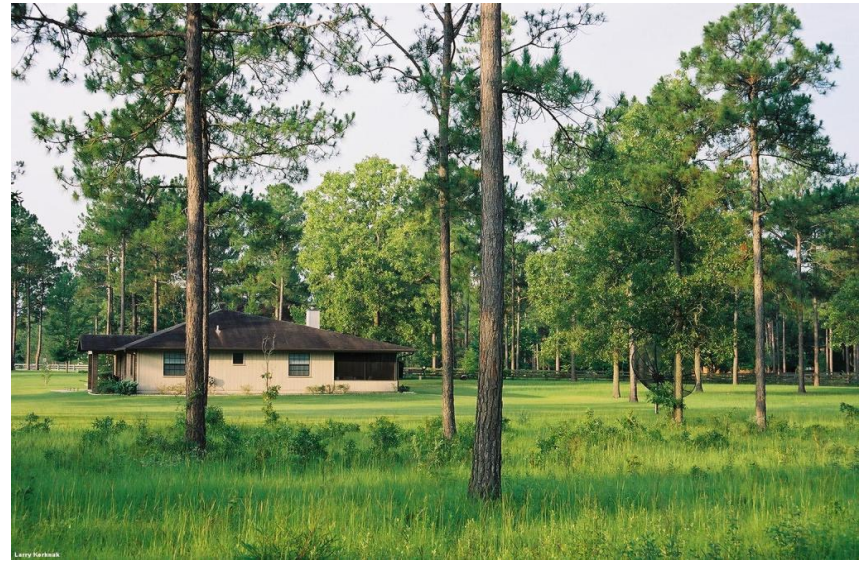

Figure 3. The best way to minimize risk of fire damage is to reduce fuels around the structure. Credits: Photo: Larry Korhnak

areas, extensive site preparation must take place in order to keep non-native invasive species from reseeding after a burn. Control of this seed source can be both time-consuming and expensive. Natural resource managers also must work with interface communities prior to and after a burn to address concerns about perceived air quality issues related to the smoke, reduced visibility on highways due to smoke, water quality issues related to increased runoff from exposed mineral soil, and concerns about causing harm to wildlife.

In addition, prescribed fire can be expensive (but usually less so than other methods). Labor and expertise in planning and implementing prescribed fire create significant costs, and often this labor and expertise are in short supply. Burning costs between $\$ 3$ per acre in very rural areas and $\$ 50$ dollars per acre at the interface (Monroe 2002). Burning is more expensive in urban areas than it is in rural areas due to an increased amount of preparation and public relations required. Concerns about liability greatly restrict burning in interface areas. Some states, for example Florida, have addressed this issue through legislation that limits liability of individuals who are conducting prescribed burns according to state and local regulations, have taken a training course, and have become certified as prescribed burn managers (Long 1999).

Herbicides provide another management tool to reduce fuel loads. Their primary benefit is fuel reduction over time, but they also help control the spacing of crop trees and change species 
composition. While cost-effective and relatively low-risk to the environment if applied correctly, herbicide use also faces intense scrutiny by a public concerned about pollution and health risks. A recent study performed in Florida ranked herbicide use as the least socially acceptable treatment for fuel reduction (Monroe 2002). Timing of herbicide applications must consider the potential increased risk of fire caused by creating a source of dead and dry fuel. For example, herbicide application before the wet season may reduce risk of wildfire, while herbicide application before the dry season may increase short-term risk of fire by creating additional fuels. Herbicide provides a long-term benefit because it reduces resprouting. A number of herbicides are regulated by state law for use in forest ecosystems.

Animal grazing uses goats and other animals to reduce and control vegetation that might serve as ladder fuels that endanger structures. Fenced areas can accommodate cattle, horses, sheep, or goats that will maintain a pasture-like fire break. Some local ordinances, however, do not allow domestic livestock in residential areas. Grazing fields surrounding communities can maintain large fire breaks that greatly reduce the risk of wildfire spreading into a community.

\section{References}

Behm, A.; A. Long; M. C. Monroe; C. Randall; W. Zipperer; and A. Hermansen-Báez. 2004. Fire in the Wildland-Urban Interface: Preparing a Firewise Plant List for WUI Residents (Circular 1453). Gainesville FL: University of Florida, Institute of Food and Agricultural Sciences, Florida Cooperative Extension Service, School of Forest Resources and Conservation, http://edis.ifas.ufl.edu/FR151 (accessed December 14, 2004).

Brose, P. and D. Wade. 2002. Potential fire behavior in pine flatwood forest following three different fuel reduction techniques. Forest Ecology and Management 163: 71-84.

Doran, J. D.; C. K. Randall; and A. J. Long. 2004. Fire in the Wildland-Urban Interface: Selecting and Maintaining Firewise Plants for Landscaping (Circular 1445). Gainesville FL: University of Florida, Institute of Food and Agricultural Sciences,
Florida Cooperative Extension Service, School of Forest Resources and Conservation, http://edis.ifas.ufl.edu/FR147 (accessed December $14,2004)$.

Gramley, M. 2005. Fire in the South: A Report by the Southern Group of State Foresters. Winder GA: Southern Group of State Foresters, http://216.226.177.78/PDFs/fire_in_the_south.pdf (accessed August 12, 2005).

Haines, T. K.; R. L. Busby; and D. A. Cleaves. 2001. Prescribed burning in the South: Trends, purpose, and barriers. Southern Journal of Applied Forestry 25(4): 149-153.

\section{Long, A. J. 1999. Prescribed Burning} Regulations in Florida (FOR 67). Gainesville FL: University of Florida, Florida Cooperative Extension, Institute of Food and Agricultural Sciences, School of Forest Resources and Conservation, http://edis.ifas.ufl.edu/FR055 (accessed May 18, 2005).

Long, A. J. and C. Randall. 2004. Wildfire Risk Assessment Guide for Homeowners in the Southern United States. Gainesville FL: University of Florida, School of Forest Resources and Conservation. USDA Forest Service Southern Center for Wildland-Urban Interface Research and Information, http://www.interfacesouth.org/fire/WildfireRAGH.pdf (accessed December 14, 2004).

Monroe, M. C. 2002. Fire. In: Human Influences on Forest Ecosystems: The Southern Wildland-Urban Interface Assessment (Gen. Tech. Rep.SRS-55). Eds. E. A. Macie and L. A. Hermansen, 133-160. Asheville NC: U.S. Department of Agriculture, Forest Service, Southern Research Station.

Monroe, M. C.; G. Babb; and K. A. Heuberger. 1999. Designing a Prescribed Fire Demonstration Area (FOR 64). Gainesville FL: University of Florida, Institute of Food and Agricultural Sciences, Florida Cooperative Extension Service, School of Forest Resources and Conservation, http://edis.ifas.ufl.edu/pdffiles/FR/FR06000.pdf (accessed June 8, 2004). 
Monroe, M. and K. Nelson. 2004. The value of assessing public perceptions: Wildland fire and defensible space. Applied Environmental Education and Communication 3: 109-117.

National Firewise Organization, 2005. http://www.firewise.org (accessed December 14, 2004).

National Interagency Fire Center, 2005, http://www.nifc.gov/preved/comm_guide/wildfire/ index2.html (accessed December 14, 2004).

Southern Center for Wildland-Urban Interface Research and Information, 2004. http://www.interfacesouth.org/fire/ (accessed December 14, 2004).

Williston, H. L.; W. E. Balmer; and D. Tomczak. 2001. Managing the Family Forest in the South. Atlanta GA: USDA, Forest Service, Southern Region. 